fournal of Medical Genetics (1975). 12, 1.

\title{
Oesophageal atresia in the South West of England
}

\author{
T. J. DAVID* and SARAH E. O'CALLAGHAN \\ From the Cardiac Department, Bristol General Hospital, Bristol BS1 6SY
}

\begin{abstract}
Summary. A retrospective anatomical and family study was made of 345 patients with oesophageal atresia who were born in the South West of England between 1942 and 1973. There were 186 males and 159 females. Twenty-one cases were stillborn.

Eighty-five per cent of the patients had a combination of oesophageal atresia with a tracheo-oesophageal fistula to the distal oesophageal segment, and $9 \%$ had atresia without a fistula. Fifty-five per cent of the patients had other congenital malformations and these tended to be multiple rather than single. Thirty-six per cent of singletons had unequivocal fetal growth retardation, and there is some evidence that nearly all cases have poor fetal growth.

There appeared to be a maternal age effect, with an excess of mothers under 20 and over 35, and there was an unexplained excess of fathers employed in the Armed Forces. Ten per cent of the cases were illegitimate. There were 21 twins which is nearly three times the expected number; there were two pairs of twins concordant for oesophageal atresia, one being monozygotic and the other dizygotic. In one case there were two sibs with oesophageal atresia. Five out of 365 sibs had anencephaly. The blood group distributions of the patients and their mothers did not significantly differ from the expected distribution.

Oesophageal atresia is aetiologically heterogenous. In this series there were at least five, and probably 10 cases of trisomy 18 , and four cases of trisomy 21 . Five mothers had overt diabetes, and there is some suggestion from other work that maternal diabetes or its treatment may be aetiologically important. Oesophageal atresia was part of a possibly recessively inherited malformation syndrome in two cases. A sibship with a case of rectal atresia, a case of Hirschprung's disease and a case of oesophageal atresia may represent the action of another recessive gene. It seems likely that oesophageal atresia is a rather non-specific consequence of several teratological processes.
\end{abstract}

It is strange that although oesophageal atresia has attracted much surgical interest there has been no large systematic study of the aetiological background to this congenital malformation. In view of this gap in our knowledge, the present survey has been performed.

Oesophageal atresia, with or without a tracheooesophageal fistula, is a fairly common congenital malformation, occurring in approximately 0.3 per

Received 4 June 1974.

* Present address: Bristol Royal Hospital for Sick Children, Bristol B52 8BJ.
1000 births (Hamilton, 1969). Most large series show a small male preponderance. Oesophageal atresia is a recognized but unusual feature of thalidomide embryopathy (Warkany, 1971). Oesophageal atresia is also known to be associated with trisomy 21 (Potts and Idriss, 1960; Holder et al, 1964; Wayson et al, 1965; Krishinger and Woolley, 1969) and trisomy 18 (Holman et al, 1963; Warkany, Passarge, and Smith, 1966; Rabinowitz et al, 1967; Grosfeld, Kontras, and Sommer, 1971; Gordon et al, 1974), and it has been found in a cytogenetic variant $(46, \mathrm{XY} / 45, \mathrm{XY}, \mathrm{D}-/ 46, \mathrm{XY}, \mathrm{Dq}+)$ of Orbeli's 
syndrome (Lazjuk et al, 1973). Patients with the DiGeorge syndrome of agenesis of the thymus and hypoplasia of the parathyroids may have associated defects of the fourth aortic arch (right-sided aortic arch or an aberrant right subclavian artery) as well as oesophageal atresia (Freedom, Rosen, and Nadas, 1972). Oesophageal atresia has also been described in association with the Holt-Oram syndrome (Harris and Osborne, 1966), with the asplenia syndrome (Freedom, 1972), and the 'triad' syndrome of abdominal muscle deficiency, renal and urinary tract dysplasia, and cryptorchidism (Myers, 1973).

Oesophageal atresia is generally regarded as a non-genetic entity. Yet there are a number of case reports of multiple affected individuals within a family. Oesophageal atresia has been reported in two affected sibs (Grieve and McDermott, 1939; Lanman, 1940; Copleman, Cannata, and London, 1950; Sloan and Haight, 1956; Haight, 1957; Fujimoto and Manabe, 1962; Hamilton, 1969; Schimke, Leape, and Holder, 1972); in the Grieve and McDermott family the parents were third cousins. Oesophageal atresia has also been reported in three sibs (Mackenzie, 1884; Hausman, Close, and Williams, 1957; Forrester and Cohen, 1970). In the Forrester and Cohen report, two of the three affected sibs also had a laryngeal fissure, suggesting that this association may be a separate entity. Oesophageal atresia has also been recorded in two consecutive generations (Engel et al, 1970; Dennis, Nicholas, and Kovar, 1973). Other possible familial cases have been reviewed by Rutten (1962).

There is a slight suggestion, from two papers on diabetes and congenital malformations, that oesophageal atresia may occur more often than expected in the offspring of diabetic mothers (Kučera, 1971; Cohen and Schenker, 1972). Oesophageal atresia can be associated with the caudal regression syndrome of absence of the sacrum, rectal atresia, absence of the external genitalia, renal agenesis, absence of the bladder, single umbilical artery, and fusion of the lower limbs (Kučera and Lenz, 1967; Källén and Winberg, 1974). Since the caudal regression syndrome is thought by some to be a fairly specific malformation of infants of diabetic mothers (Kučera, 1971), the possible association of oesophageal atresia and gestational diabetes clearly needs further investigation. Perhaps the most striking features of oesophageal atresia are firstly, the very high proportion of cases who have other major malformations and second, that it is a malformation that has not been produced with any regularity in teratological experiments (Warkany, 1971). Although Kalter and Warkany (1957) found oesophageal atresia in the offspring of female mice that received a riboflavin-deficient galactoflavin-containing diet, there were no tracheo-oesophageal fistulas, whereas in man the two lesions usually co-exist.

Twins are usually discordant for oesophageal atresia, but concordant monozygotic twins have been recorded on five occasions (Panse and Gierlich, 1949; Woolley, Chinnock, and Paul, 1961; Blank, Prillaman, and Minor, 1967; Farha, Diener, and Block, 1971; Bolam et al, 1973). However, as will be shown, twin studies are likely to be misleading in estimating the relative importance of genetic or environmental factors in the aetiology of oesophageal atresia.

\section{Materials and methods}

Cases included in this study had either: (1) oesophageal atresia only, or (2) oesophageal atresia with a tracheo-oesophageal fistula, or (3) a tracheo-oesophageal fistula only.

They were traced in the following ways: (a) Through diagnostic indices of medical records departments at the Bristol Royal Hospital for Sick Children and Frenchay Hospital, Bristol. (b) Through diagnostic indices compiled by thoracic surgeons, Mr R. H. R. Belsey, Mr J. L. Griffith, and Mr G. Keen, in the South West of England. (c) Through diagnostic indices compiled by $\mathrm{Dr}$ N. J. W. Royston and Dr B. W. Webb, Consultant Paediatricians in Taunton, and Dr F. S. W. Brimblecombe, Consultant Paediatrician in Exeter. (d) Through necropsy diagnostic indices at Southmead Hospital, Bristol (compiled by Dr N. J. Brown) and the University of Bristol Pathology Department. (e) By hand searching of every necropsy report at Frenchay Hospital, Bristol (by courtesy of Dr R. J. Sandry); Taunton and Somerset Hospital (Musgrove Park, Taunton, branch-by courtesy of Dr E. J Harries); and the Royal Devon and Exeter Hospital (Wonford), Exeter (by courtesy of Dr R. A. Caldwell); (f) By hand searching of admissions books of all admissions to the special care baby units of the Bristol Royal Hospital for Sick Children, the Royal Devon and Exeter (Heavitree) Hospital, Exeter, and the Musgrove Park branch of the Taunton and Somerset Hospital, Taunton.

The hospital records of every live born case were examined, and whenever possible ante-natal details were obtained from hospital ante-natal records and from the general practitioner. Although the earliest case was born in 1942, before National Health Service Records had been started, it was nevertheless possible to obtain nearly complete ante-natal data in $90 \%$ of the cases.

\section{Results}

Three hundred and forty-five cases, born in the South West of England between 1942 and 1973, were studied. Half the cases were born before 1964 . The total of 345 cases included 186 males and 159 females, a sex ratio of 1.17. Twenty-one cases were stillborn. Necropsy had been performed in 153 of the 172 cases $(89 \%)$ who had died or were 
stillborn. The incidence of oesophageal atresia was estimated to be 0.34 per 1000 births (David and O'Callaghan, 1974a).

\section{Anatomical study}

Type of oesophageal defect. Two hundred and ninety-four cases $(85.2 \%$ ) had the combination of oesophageal atresia with a tracheo-oesophageal fistula to the distal oesophageal segment. Thirtytwo cases $(9.3 \%)$ had oesophageal atresia only, without a fistula. Seven cases $(2.0 \%)$ had oesophageal atresia and a fistula connecting the distal oesophageal segment to the left or right main bronchus (instead of the trachea). Six cases $(1.7 \%)$ had oesophageal atresia with a tracheo-oesophageal fistula to both the upper and lower oesophageal segments. Four cases $(1.2 \%)$ had a tracheo-oesophageal fistula without oesophageal atresia. One case had oesophageal atresia, tracheal agenesis, and a fistula from the proximal oesophageal segment to the left and right main bronchi. One case had a common tracheooesophagus.

Other malformations. One hundred and fifty-six cases ( $45 \%$ ) had no other malformations. The frequency of other malformations is shown in Table I.

TABLE I

OTHER MALFORMATIONS BY SYSTEM

\begin{tabular}{l|c|c|c}
\hline \multicolumn{1}{c|}{ System } & Total & $\begin{array}{c}\text { No Other } \\
\text { System } \\
\text { Affected }\end{array}$ & $\begin{array}{c}\text { Other } \\
\text { Systems } \\
\text { Affected }\end{array}$ \\
\hline Cardiovascular & $96(28 \%)$ & $26(27 \%)$ & $70(73 \%)$ \\
Gastrointestinal & $78(23 \%)$ & $19(24 \%)$ & $59(76 \%)$ \\
Genitourinary & $64(19 \%)$ & $11(17 \%)$ & $53(83 \%)$ \\
Skeletal & $61(23 \%)$ & $10(16 \%)$ & $51(84 \%)$ \\
Others & $78(23 \%)$ & $18(23 \%)$ & $60(77 \%)$ \\
\hline
\end{tabular}

Cardiovascular malformations were not only the most frequently associated defects, but they also carried the worst prognosis, and they have therefore been studied separately (David and O'Callaghan, 1974b). A single umbilical artery was recorded in 13 cases, but was not classified as a malformation. For this study, a persistent ductus arteriosus was classified as a cardiovascular malformation, pyloric stenosis was classified as a gastrointestinal malformation, but hiatus hernia was not classified as a malformation. The other malformations, excluding cardiovascular malformations, and their exact numbers are given in Table II; they are listed in order of frequency in systems. Single cases are represented more than once where more than one other malformation was present.
Fetal growth. Birth weight and gestation were known in 294 out of 324 singletons with oesophageal atresia. In these cases the fetal growth rate was assessed using the centile charts of Thomson, Billewicz, and Hytten (1968). The results are given in Table III. If one takes infants below the fifth centile as showing unequivocal fetal growth retardation, then at least 105 cases $(36 \%)$ of oesophageal atresia had fetal growth retardation. Indeed, only $31 \%$ were on or above the 25 th centile. Of the 105 cases below the fifth centile, 29 had no other malformations, 38 had cardiovascular malformations, 29 had genitourinary malformations, 29 had gastrointestinal malformations, 36 had skeletal malformations, and 38 had other defects.

\section{Family study}

Father's occupation. The father's occupation was recorded in 228 cases ( $66 \%$ ). There appeared to be an excess of fathers-28 $(12.3 \%)$-in the Armed Forces (nine Army, 10 Navy, nine Royal Air Force). However, the father's occupation is more likely to be recorded in the hospital records if the father is in the Armed Forces, and it would be better to consider that the figure of 28 includes all fathers in the Armed Forces for the whole series of 345 cases, giving a smaller percentage of $8.1 \%$. Even so, calculating the expected figures from the South West of England figures in the 1961 or 1966 Census, there is still an excess of fathers in the Armed Forces which is significant at the 1 in 20 and 1 in 1000 levels, respectively (Table IV). Since one might expect more men to be in the Armed Forces both during the war and after the war when conscription was operating (it ended in 1958), we have taken the figures for the father's occupation from 1962 onwards (see Table IV). The figures then actually show a slightly higher proportion of fathers in the Armed Forces; because of the smaller numbers this does not quite reach statistical significance at the 1 in 20 level for the 1961 Census figures but it is significant at the 1 in 100 level for the 1966 Census figures.

Social class. The social class distribution of the fathers was not significantly different from the expected distribution (Table V) using figures for the South West of England from the 1966 Census to calculate the expected figures.

Legitimacy. There were 36 illegitimate cases (10\%).

Maternal age and birth order. The maternal age could not be ascertained in 95 cases $(28 \%)$, and the birth order was not known in 42 cases (12\%). The 
TABLE II

OTHER MALFORMATIONS IN 345 CASES OF OESOPHAGEAL ATRESIA

Gastrointestinal system

Rectal atresia (with fistula in 19)

Duodenal atresia

Malrotation

Abnormal gallbladder

Meckel's diverticulum

Splenunculus

Pyloric stenosis

Cavernous haemangioma of liver

Abnormal liver

Exomphalos

Absent spleen

Agenesis of colon

Duplication of stomach

Duplication cyst of duodenum

Duplication cyst of duodenum

Ectopic glandular acini and ducts on peritoneal surface of stomach

Genitourinary system

Renal agenesis (bilateral in 8)

Hydronephrosis (bilateral in 5)

Horseshoe kidney

Hypoplastic kidney

Hydroureter without specified obstruction

Absent or abnormal uterus

Abnormal external genitalia (female)

Hypospadias

Polycystic kidney (bilateral in 2)

Cryptorchidism

Stenosis of pelvi-ureteric junction

Vaginal atresia

Urethral atresia

Absent Fallopian tube and ovary

Other renal anomaly

Unilateral absent testis

Urethral valve

Patent urachus

Vesico-uterine fistula

Skeletal system

Radial upper limb defects (radial club hand, absent

thumb, absent or hypoplastic radius)

Vertebral defects

Rib defects

Skeletal system-contd

Talipes equino-varus

Congenital dislocation of hip

Defects of tibia or fibula

Scoliosis

Short sternum, absent xiphisternum

Absent right arm and hand, with phocomelia right leg

Hypoplastic big toe

Arachnodactyly

Cleft left hand; absent middle finger

Sacral agenesis

Bilateral absent radius and ulna

Post-axial polydactyly

Other defects

Abnormal ears

Hydrocephalus

Incomplete division of lobes of lung or missing lobe

Diaphragmatic hernia (4 left, 1 right)

Trisomy 18

Trisomy 21

Unilateral absent lung

Abnormal larynx

Cleft palate

Inguinal hernia

Tracheal stenosis

Skull defect

Facial palsy

Squint

Microcephaly

Occipital meningocoele

Microphthalmia

Cataracts

Tracheal atresia

Left eyelids fused

Micrognathos

Absent mandible

Sirenomelia

Monster

Left hemiatrophy

Hare lip

Hydrocoele

Lumbar spina bifida

Cervical spina bifida with anencephaly

Absent visual cortex

Colobomata of iris
Stricture of bronchus

t Not due to thalidomide.

* These patients had trisomy 18.

TABLE III

WEIGHT FOR DATES OF SINGLETONS WITH OESOPHAGEAL ATRESIA Estimated on the charts of Thomson et al (1968)

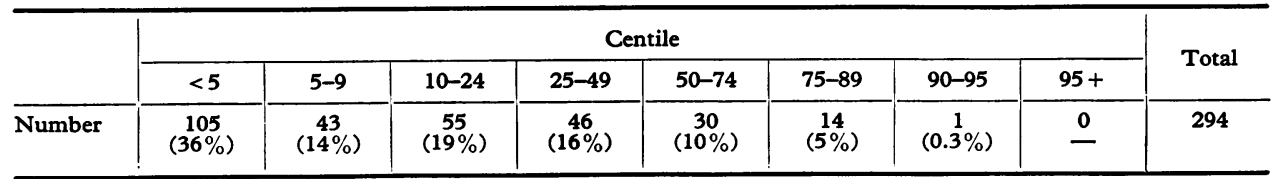

TABLE IV

FATHERS IN THE ARMED FORCES

\begin{tabular}{l|l|l}
\hline & $\begin{array}{l}1942-1973 \\
(345 \text { cases })\end{array}$ & $\begin{array}{l}1962-1973 \\
(214 \text { cases })\end{array}$ \\
\hline Observed in the present series & $28(8.1 \%)$ & $18(8.4 \%)$ \\
Expected (from 1961 Census figures) & $18.4^{*}$ & $11.4 \ddagger$ \\
Expected (from 1966 Census figures) & $14.2 \dagger$ & $8.8^{* *}$ \\
\hline
\end{tabular}

$* x_{(1)}^{2}=4.8, \mathrm{p}<0.05$.

† $\chi_{(1)}^{2}=13.0, \mathrm{p}<0.001$

$\ddagger x_{(1)}^{2}=3.5$, not significant. $\quad * * x_{(1)}^{2}=9.0, \mathrm{p}<0.01$.
TABLE V

FATHER'S SOCIAL CLASS

\begin{tabular}{|c|c|c|c|c|c|}
\hline & 1 & 2 & 3 & 4 & 5 \\
\hline $\begin{array}{l}\text { Observed } \\
\text { Expected }\end{array}$ & $\begin{array}{l}16 \\
9.8\end{array}$ & $\begin{array}{l}28 \\
43.2\end{array}$ & $\begin{array}{l}114 \\
109.1\end{array}$ & $\begin{array}{l}50 \\
46.7\end{array}$ & $\begin{array}{l}20 \\
19.2\end{array}$ \\
\hline
\end{tabular}


maternal age and birth order distribution of legitimate cases was compared with the expected number estimated from the distribution of legitimate births in the Registrar General's 1964 figures for England and Wales. The figures are shown in Table VI. The distribution by maternal age standardized for birth order, and birth order standardized for maternal age, is shown in Tables VII and VIII. The observed maternal age distribution (Table VII) deviates from the expected at the 1 in 1000 level of

\section{TABLE VI}

DISTRIBUTION BY MATERNAL AGE AND NUMBER OF PREVIOUS LIVE BORN SIBS COMPARED WITH THE EXPECTED DISTRIBUTION. SINGLETONS AND TWINS

\begin{tabular}{|c|c|c|c|c|c|c|c|}
\hline \multirow{2}{*}{$\begin{array}{c}\text { Maternal } \\
\text { Age }(\mathrm{yr})\end{array}$} & \multicolumn{6}{|c|}{ Birth Order } & \multirow{2}{*}{ Total } \\
\hline & 0 & 1 & 2 & 3 & 4 & $5+$ & \\
\hline $\begin{array}{l}\mathrm{O}_{\mathrm{E}}^{<20} \\
\end{array}$ & $\begin{array}{l}24 \\
12.90\end{array}$ & $\begin{array}{l}3 \\
2.94\end{array}$ & $\begin{array}{l}1 \\
0.32\end{array}$ & $\begin{array}{l}0 \\
0.02\end{array}$ & $\begin{array}{l}0 \\
0\end{array}$ & $\begin{array}{l}0 \\
0\end{array}$ & $\begin{array}{l}28 \\
16.18\end{array}$ \\
\hline $\begin{array}{l}20-24 \\
\mathrm{O} \\
\mathrm{E}\end{array}$ & $\begin{array}{l}34 \\
35.95\end{array}$ & $\begin{array}{l}25 \\
23.02\end{array}$ & $\begin{array}{l}4 \\
7.67\end{array}$ & $\begin{array}{l}2 \\
2.13\end{array}$ & $\begin{array}{l}0 \\
0.5\end{array}$ & $\begin{array}{l}0 \\
0.12\end{array}$ & $\begin{array}{l}65 \\
69.39\end{array}$ \\
\hline $\begin{array}{l}25-29 \\
\mathrm{O} \\
\mathrm{E}\end{array}$ & $\begin{array}{l}19 \\
19.74\end{array}$ & $\begin{array}{l}22 \\
25.74\end{array}$ & $\begin{array}{c}8 \\
13.85\end{array}$ & $\begin{array}{l}4 \\
6.01\end{array}$ & $\begin{array}{l}2 \\
2.48\end{array}$ & $\begin{array}{l}0 \\
1.54\end{array}$ & $\begin{array}{l}55 \\
69.36\end{array}$ \\
\hline $\begin{array}{l}30-34 \\
\mathrm{O} \\
\mathrm{E}\end{array}$ & $\begin{array}{l}12 \\
6.19\end{array}$ & $\begin{array}{c}9 \\
11.20\end{array}$ & ${ }^{11} 9.62$ & $\begin{array}{l}4 \\
5.50\end{array}$ & $\begin{array}{l}0 \\
2.88\end{array}$ & $\begin{array}{l}0 \\
3.12\end{array}$ & $\begin{array}{l}36 \\
38.51\end{array}$ \\
\hline $\begin{array}{l}35-39 \\
\text { O } \\
\mathbf{E}\end{array}$ & $\begin{array}{l}3 \\
2.09\end{array}$ & $\begin{array}{l}4 \\
3.70\end{array}$ & $\begin{array}{l}6 \\
4.23\end{array}$ & $\begin{array}{l}2 \\
3.13\end{array}$ & $\begin{array}{l}3 \\
1.98\end{array}$ & $\begin{array}{l}2 \\
3.09\end{array}$ & $\begin{array}{l}20 \\
18.22\end{array}$ \\
\hline $\begin{array}{l}40+ \\
O \\
\text { E }\end{array}$ & $\begin{array}{l}4 \\
0.45\end{array}$ & $\begin{array}{l}2 \\
0.76\end{array}$ & $\begin{array}{l}0 \\
1.02\end{array}$ & $\begin{array}{l}3 \\
0.96\end{array}$ & $\begin{array}{l}1 \\
0.70\end{array}$ & $\begin{array}{l}3 \\
1.47\end{array}$ & ${ }^{13} 5.36$ \\
\hline Total & $\begin{array}{l}96 \\
77.32\end{array}$ & $\begin{array}{l}65 \\
67.36\end{array}$ & $\begin{array}{l}30 \\
36.71\end{array}$ & $\begin{array}{l}15 \\
17.75\end{array}$ & $\begin{array}{l}6 \\
8.54\end{array}$ & $\begin{array}{l}5 \\
9.34\end{array}$ & 217 \\
\hline
\end{tabular}

TABLE VII

DISTRIBUTION BY MATERNAL AGE STANDARDIZED FOR BIRTH ORDER. SINGLETONS AND TWINS

\begin{tabular}{l|l|l|l|l|l|l|l}
\hline & \multicolumn{5}{|c|}{ Maternal Age (yr) } & Total \\
\cline { 2 - 6 } & $<20$ & $20-24$ & $25-29$ & $30-34$ & $35-39$ & $40+$ & \\
\hline $\mathrm{O}$ & 28 & 65 & 55 & 36 & 20 & 13 & 217 \\
\hline & 16.17 & 69.40 & 69.35 & 38.51 & 18.21 & 5.36 & \\
\hline
\end{tabular}

TABLE VIII

DISTRIBUTION BY NUMBER OF PREVIOUS LIVE BORN SIBS, STANDARDIZED FOR MATERNAL AGE. SINGLETONS AND TWINS

\begin{tabular}{|c|c|c|c|c|c|c|c|}
\hline & \multicolumn{6}{|c|}{ Birth Order } & \multirow{2}{*}{ Total } \\
\hline & 0 & 1 & 2 & 3 & 4 & $5+$ & \\
\hline $\begin{array}{l}\mathrm{O} \\
\mathrm{E}\end{array}$ & $\begin{array}{l}96 \\
77.33\end{array}$ & $\begin{array}{l}65 \\
67.35\end{array}$ & $\begin{array}{l}30 \\
36.71\end{array}$ & $\begin{array}{l}15 \\
17.75\end{array}$ & $\begin{array}{l}6 \\
8.53\end{array}$ & $\begin{array}{l}5 \\
9.34\end{array}$ & 217 \\
\hline
\end{tabular}

significance; the excess of observed over expected is for mothers both under 20 and over 35 years. The largest excess, that of mothers under 20 , is in mothers with no previous live born children (Table VI). The birth order distribution standardized for maternal age (Table VIII) shows no statistically significant deviation from the expected figures.

Twins. There were 21 twins, which is over twice and nearly three times the expected figure of 7.9 estimated from the Registrar General's figures for England and Wales for 1964. An association between oesophageal atresia and twinning is evident both in the present series and some previous series, and this association has been studied separately (David and O'Callaghan, 1974c). The increase in twins applied to both monozygotic and dizygotic twins. There were two pairs of twins concordant for oesophageal atresia, one pair being monozygotic and the other dizygotic.

Sibs with malformations. No attempt was made to visit all the families to get information about sibs. In the 303 cases where information about sibs was available (from hospital and general practitioner records), and excluding the four twins from the two concordant pairs, there were 340 older sibs (including stillbirths). Special efforts to find out about younger sibs were not made, but information about 25 younger sibs was found in some sets of ante-natal records. Thus, there was information on 365 sibs. In only one case was there a sib (or any other relative) with oesophageal atresia. This was a boy with oesophageal atresia and rectal atresia. His parents moved away from the South West of England, and have had three further children of whom two had oesophageal atresia, rectal atresia, and a laryngeal fissure. This family have been documented by the physician and surgeon who looked after the latter two cases (Forrester and Cohen, 1970). The other malformations in sibs are listed in Table IX.

TABLE IX MALFORMATIONS IN SIBS OF CASES OF OESOPHAGEAL ATRESIA

Anencephaly (with spina bifida in one)

Spina bifida alone

Hydrocephalus (aqueduct stenosis)

Rectal atresia

Hirschprung's disease

Hentricular septal defect

Contricular septal defect

Fallot's tetralogy.

Cardiomyopathy

Cleft lip and palate

Hypospadias

Un-named multiple malformation syndrome

Fanconi's syndrome

Malformation syndrome with absent radius, ulna, external

auditory meatus, hypoplastic auricle, rectal atresia 
Malformations in other relatives. One father had pulmonary valve stenosis, but otherwise the parents did not have any known congenital malformations. Owing to the poor survival of cases of oesophageal atresia in the early years of this survey, there are only $\mathbf{2 2}$ cases over 18 years of age, and as far as has been possible to ascertain, none of these have had any children.

Blood groups. The blood group distributions of the cases (Table X) and their mothers (Table XI) were compared with the expected distribution estimated from the figures for the South West of England published by Kopeć (1970). Both distributions show no statistically significant deviation from the expected figures.

TABLE $X$

ABO BLOOD GROUP DISTRIBUTION OF CASES OF OESOPHAGEAL ATRESIA

\begin{tabular}{l|c|c|c|c}
\hline & $\mathrm{A}$ & $\mathrm{O}$ & $\mathrm{B}+\mathrm{AB}$ & Unknown \\
\hline Observed & 85 & 88 & 30 & 142 \\
\cline { 2 - 4 } & 91.98 & 88.45 & 22.78 & \\
\hline
\end{tabular}

TABLE XI

ABO BLOOD GROUP DISTRIBUTION OF MOTHERS

\begin{tabular}{l|c|c|c|c}
\hline & $\mathrm{A}$ & $\mathrm{O}$ & $\mathrm{B}+\mathrm{AB}$ & Unknown \\
\hline Observed & 63 & 65 & 19 & 198 \\
Expected & 66.61 & 64.05 & 16.49 & \\
\hline
\end{tabular}

\section{Discussion}

Type of oesophageal defect. The distribution of the different types of anomalies is very similar to that reported in the largest previous analysis, that of the Surgical Section of the American Academy of Pediatrics (Holder et al, 1964). In the present series, the commonest type of defect was oesophageal atresia with a distal segment tracheooesophageal fistula found in 294 cases (85.2\%). This figure is very similar to the proportion $(86.5 \%$; 916 out of 1058 cases) found by Holder $e t$ al. The proportion of cases with oesophageal atresia only in this series $(9.3 \%$ ) was a little higher than for the American series (7.7\%). However, the proportion of cases with a tracheo-oesophageal fistula only was lower in the present series $(1.2 \%)$ than in the American series (4.2\%).

There was one case of complete failure of separation of the trachea and oesophagus in the present series. In a review of this exceedingly rare condition, of which there are 12 recorded cases, there is a suggestion that this malformation may be related causally to maternal diabetes because two mothers were diabetics (Födisch and Sauer, 1972). In the present case, the mother was a 20 -year-old primipara. In addition to a common tracheo-oesophagus, the female infant had rectal atresia with a rectovesical fistula, bilateral dislocation of the hip, a ventricular septal defect, a right-sided aortic arch, an absent left kidney and a small polycystic right kidney, and a uterus didelphys with vaginal atresia. The birth weight at 32 weeks' gestation was $2169 \mathrm{~g}$, and the mother was not known to have overt diabetes.

The significance of the different types of oesophageal defect is not known, but it is clearly quite possible that, for example, oesophageal atresia with a tracheo-oesophageal fistula is aetiologically distinct from oesophageal atresia without a fistula. Rather against this possibility, though, is the fact even in familial cases of oesophageal atresia different types of oesophageal defect can occur in the same family (Hausman et al, 1957; Dennis et al, 1973), and this tends to suggest that distinguishing between different types of oesophageal lesions is unlikely to help in the detection of aetiologically different subgroups.

Associated malformations. One of the striking features of oesophageal atresia is the very high proportion of cases that have associated malformations. In the present series $55 \%$ had other malformations, which were usually multiple, and which tended to be major rather than minor defects. This proportion is very similar to previous series, though it might have been expected to be higher in view of the large number of dead cases and the high necropsy rate.

There are certain points about the associated malformations that are worth noting. In the gastrointestinal system, by far the commonest malformation, and the single malformation most commonly found in oesophageal atresia, was rectal atresia. Duodenal atresia is also fairly frequent in oesophageal atresia, being associated directly and linked indirectly by the shared association with trisomy 21 . Pyloric stenosis has emerged recently as being definitely associated with oesophageal atresia (Franken and Saldino, 1969; Ahmed, 1970; Owings, 1973), and the relationship has been specially examined recently (Glasson, Bandrevics, and Cohen, 1973). All that can be added on this subject is that none of the four cases here had any family history of pyloric stenosis, and, as with previous cases associated with oesophageal atresia, the diagnosis was overlooked until a very late stage. Not one of the gastrointestinal defects could be considered lethal, but 
this was not the case with genitourinary defects, where 15 cases had bilateral renal defects of a serious or lethal nature. Abnormal female genitalia, both internal and external, seem rather commoner in the present series than in the large series of Holder et al (1964); this may be due to the fact that these abnormalities were not considered important in the past, and inasmuch as most of these genital abnormalities are associated with other much more serious or lethal defects, this is of course still true.

Skeletal defects are not uncommon, and unfortunately tend to be rather severe, as well as often being associated with extra-skeletal malformations. Pre-axial limb defects are the commonest, followed by vertebral defects and their 'consequences' of rib defects and scoliosis. The case with sacral agenesis had multiple other malformations, but the mother, a young primipara, did not have diabetes as might have been expected. In two cases, limb defects heralded a familial syndrome. In one of these, oesophageal atresia was part of Fanconi's pancytopenia syndrome, with typical radial limb defects (Fig. 1) and chromosome abnormalities, a previous sib having died with Fanconi's syndrome but not oesophageal atresia. Another case of oesophageal atresia (Fig. 2), a male, also had an absent auditory meatus with a hypoplastic auricle, a cleft palate, absent forearms (bilateral absence of the radius and ulna) with rudimentary hands attached to the elbows, rectal and duodenal atresia. In this case there was a sib with hydrocephalus, and identical limb, ear and rectal malformations, though without a cleft palate or oesophageal atresia. There were three other normal sibs in this family, with no other family history of congenital malformations and no parental consanguinity. The two patients with a short sternum and absent xiphisternum both had trisomy 18 .

Abnormal ears, often associated with oesophageal atresia, are sometimes though not always associated with renal anomalies in these patients. Hydrocephalus, known to be associated with oesophageal atresia (Holder et al, 1964; Martin, 1965), was of the type due to stenosis of the aqueduct of Sylvius in all 13 cases, and often presented late as described by Lewis (1972). Interestingly, 10 of these 13 hydrocephalics were born in Bristol. This is very much the reverse of the geographical trend reported in the British Perinatal Mortality Survey (Butler and Alberman, 1969) where the South and South West had the lowest incidence of hydrocephalus in England, Scotland, and Wales.

Four cases had trisomy 21 , and five cases had trisomy 18 . The latter were all born after 1965 , and it is reasonable to estimate that there were at least

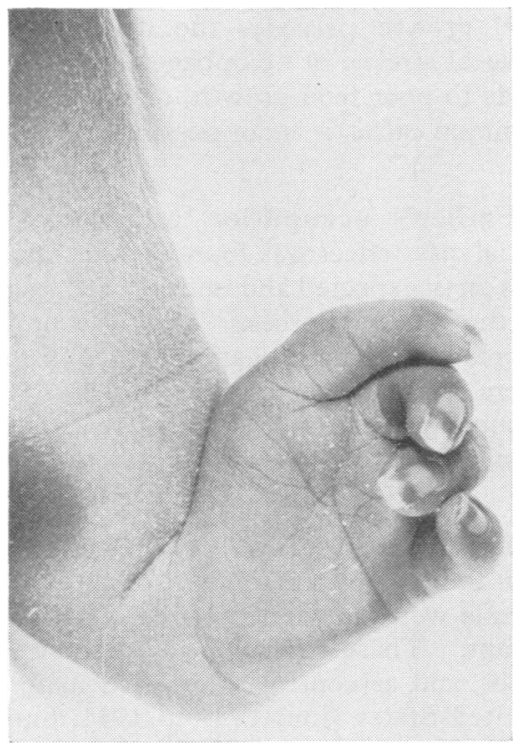

$1 \mathbf{a}$

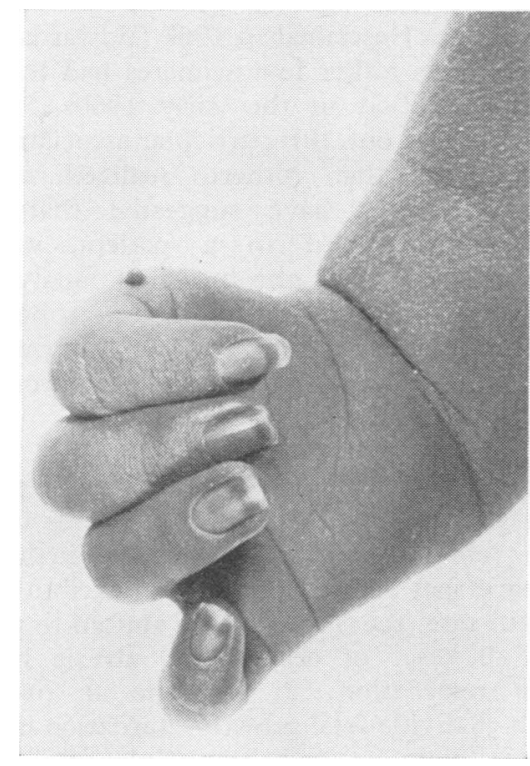

16

FIg. 1. Male neonate with Fanconi's syndrome. 1a: Left hand, showing absent radius and thumb. 1b: Right hand, showing hypoplastic radius, absent thumb, and dimple on pre-axial border of proximal phalanx of index finger. 


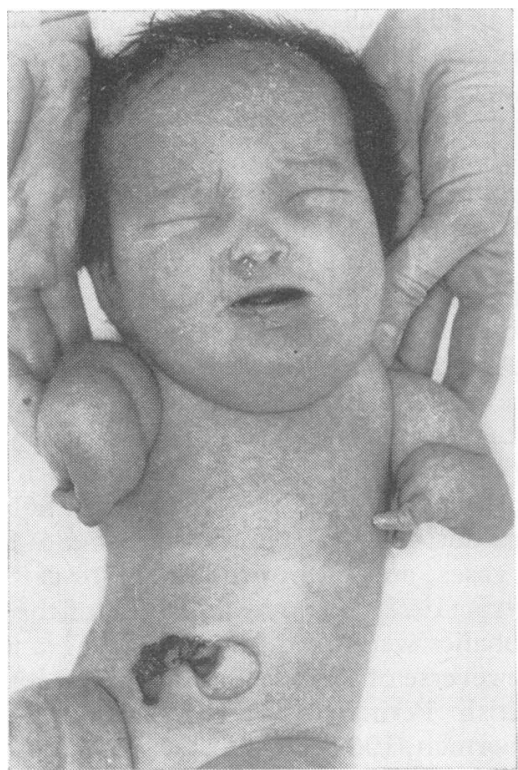

$2 a$

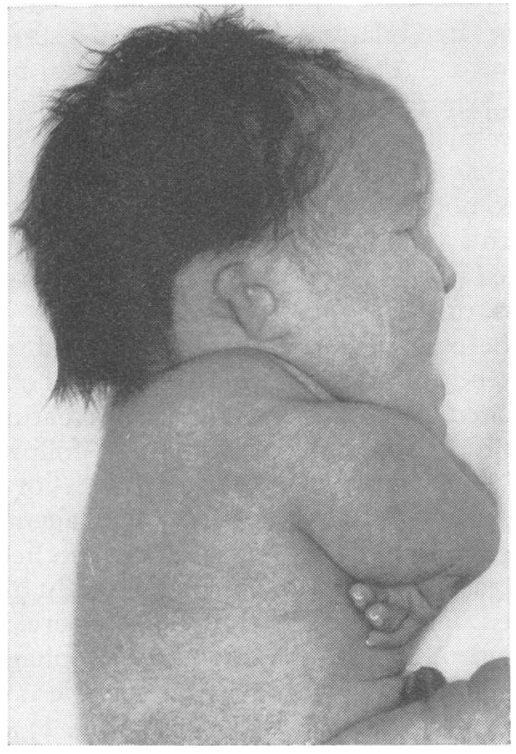

$2 b$

Fig. 2. Male neonate with multiple malformation syndrome. 2a: Absent forearms and rudimentary hands. 2b: Deformed auricle as well as deformed arm and hand.

another five cases of trisomy 18 before 1965, these other cases being unrecognized because the condition was only first described in 1960 (Edwards $e t$ $a l)$ and also because rather few neonates had their chromosomes examined in the early 1960s. As Myers (1973) pointed out, this particular association is much commoner than hitherto realized, and Grosfeld et al (1971) have suggested that if trisomy 18 is suspected in a patient with oesophageal atresia then chromosomal analysis should be performed by a rapid method on a bone marrow aspirate, so that if trisomy 18 is confirmed surgical treatment can be witheld since the syndrome is incompatible with prolonged survival.

Fetal growth. Thirty-six percent of singletons with oesophageal atresia in the present series had unequivocal fetal growth retardation. Further, one could argue that because the whole distribution of fetal growth rate (see Table III) is shifted to the left, almost all cases of oesophageal atresia had fetal growth retardation. It may be an oversimplification to divide fetal growth retardation into two groups-a 'malnourished' group (placental insufficiency, fetal malnutrition) and a 'hypoplastic' group (congenital malformations), but 76 out of 105 cases $(72 \%)$ of oesophageal atresia with fetal growth retardation had other congenital malformations and fall into the 'hypoplastic' group. Whether poor fetal growth precedes the development of oesophageal atresia, or oesophageal atresia precedes and leads to poor fetal growth, or whether they share a common cause, it is not possible to tell at present.

Father's occupation and social class. No social class effect was found in this series, but there was an unexpected and unexplained excess of fathers in the Armed Forces. This is a finding that requires further investigation and confirmation before there is any speculation as to why $8 \%$ of cases of oesophageal atresia should have fathers in the Armed Forces.

Legitimacy. Ingalls and Prindle (1949) found that four out of 102 mothers of cases of oesophageal atresia were unmarried at the birth of the affected infant. These cases were born between 1934 and 1948 , and as controls they used maternities in the United States from 1939 to 1944 , finding that the illegitimacy rate was twice as high in the cases than in the controls. This led them to suggest that in oesophageal atresia there may be an 'occasional connection' with attempted abortion. We have 
not found a satisfactory control group, but the $10 \%$ illegitimacy rate found in this series does not seem excessive.

Maternal age and birth order. In the present series there was an excess of mothers under 20 and over 35 years. This excess of young mothers was not noted by Ingalls and Prindle (1949) who did however find an excess of 'older' mothers. No significant birth order effect was found.

Twinning. Whilst an association between twinning and oesophageal atresia is evident, what this means is not at all clear. There appear to be three main possibilities. Either twinning predisposes to oesophageal atresia, or oesophageal atresia and twinning share common causative factors, or both. What is important is that in this situation an examination of the concordance or discordance for oesophageal atresia in twins cannot give any guide as to the relative importance of genetic or environmental factors in the aetiology of oesophageal atresia in general. As Edwards (1968) has pointed out: 'the assumptions that a nice simple system in which both monozygotic and dizygotic twins are exposed to similar uterine experiences and that these experiences provide data which can be applied to singletons are both untrue.'

Genetics. Recurrence of oesophageal atresia in a family occurred once in this series. In this family, previously reported elsewhere (Forrester and Cohen, 1970), the association of laryngeal fissure strongly suggests that this association of defects is a distinct entity. Although familial cases of oesophageal atresia have been reported (see above) they are rare. Adequate data on the risks to the offspring of survivors with oesophageal atresia are not yet available, and it will be a few years before there are enough numbers of survivors who have had children to know exactly what the risks are. Whether the rare familial cases are accounted for by single factor inheritance or polygenic inheritance, the rarity of affected sibs makes a major risk to the offspring of oesophageal atresia survivors unlikely, unless some cases of oesophageal atresia are due to new dominant gene mutations (which are then likely to be transmitted to half of the offspring of survivors)-only a very remote possibility.

It may be that a predisposition, genetic or otherwise, to oesophageal or rectal atresia does exist. This would account for (1) the fact that these two malformations frequently co-exist and (2) that in sibs of cases of oesophageal atresia there is an excess of cases of rectal atresia over the number that would have been expected by chance alone. Or it may be that in the two families with oesophageal atresia and rectal atresia in sibs the intestinal atresia is a non-specific effect of a recessive gene. In one family the first child, a male, had Hirschprung's disease, the second child, also a male, had rectal atresia, and the third child, a female, had oesophageal atresia without a tracheo-oesophageal fistula or any other malformations. Hirschprung's disease in the first child of this sibship is unlikely to be a chance event. Rectal atresia can be complicated by Hirschprung's disease (Passarge, 1972), and rectal atresia is quite frequently complicated by aganglionic megacolon particularly when the aganglionic segment is specifically looked for (Parkkulainen, Hjelt, and Sulamaa, 1959/1960), and Hirschprung's disease has been reported in two sibs with a third sib who had rectal atresia (Madsen, 1964). So, in this family at least, there may be a common link between oesophageal atresia, rectal atresia and Hirschprung's disease.

Anencephaly is not particularly associated with oesophageal atresia, and only one case in this series had anencephaly. This case, a twin, had a remarkable constellation of malformations, of which oesophageal atresia was merely a small part. The cotwin had a similar constellation of malformations which included iniencephaly but not oesophageal atresia. Yet, in this series, no less than five out of 365 sibs had anencephaly, a finding that is intriguing and difficult to explain.

There were two cases of oesophageal atresia with other malformations where a non-twin sib had similar malformations which did not include oesophageal atresia. In one of these sib-pairs the malformations were clearly part of the Fanconi syndrome, which is known to be inherited as an autosomal recessive. It appears that oesophageal atresia has not been reported in association with Fanconi's syndrome before, though this association is likely to be overlooked if the patient died in the neonatal period. In the other sib-pair the sib with oesophageal atresia had an absent auditory meatus and a hypoplastic auricle, a cleft palate, absent forearms with rudimentary hands attached at the elbows, and rectal and duodenal atresia. The sib without oesophageal atresia had hydrocephalus, with identical ear, limb, and rectal malformations, though it did not have a cleft palate or duodenal atresia. There were three normal sibs, and no other family history of congenital malformations, nor was there any consanguinity. In view of the similarity of the malformations in these sibs the condition may be due to a recessive gene. 


\section{Conclusions}

There is no doubt that oesophageal atresia is aetiologically heterogeneous. In the present series there were at least five, and probably 10 , cases of trisomy 18 and four cases of trisomy 21. There were no known cases of thalidomide embryopathy. There were five mothers who had overt diabetes mellitus, though in none of their offspring with oesophageal atresia were there malformations supposed to be characteristic of the embryopathy related to maternal diabetes or its treatment, and the precise relationship of oesophageal atresia to maternal diabetes remains to be elucidated. There were no recognized cases of the DiGeorge syndrome, although there were 12 cases with a right-sided aortic arch and seven with an aberrant right subclavian artery which can be associated with the DiGeorge syndrome. There was only one case of familial oesophageal atresia, but in two cases oesophageal atresia was part of a possibly recessively inherited malformation syndrome, and the sibship with a case of rectal atresia, a case of Hirschprung's disease, and a case of oesophageal atresia may represent the action of another recessive gene. Twinning is associated with oesophageal atresia, though whether this is a cause and effect relationship or not is unknown. There appears to be a maternal age effect in oesophageal atresia with mothers under 20 and over 35 being particularly at risk, and there is an unexplained excess of fathers in the Armed Forces.

It seems likely that oesophageal atresia is a rather non-specific consequence of several teratological processes. Progress in the future will depend on the ability to recognize aetiological entities within a group of apparently similar malformations.

The authors would like to thank Dr F. S. W. Brimblecombe, Mrs A. Hoskins, Dr N. J. W. Royston, and Dr B. W. Webb for their help; Dr D. W. Barritt, Dr D. Burman, Professor N. R. Butler, Dr C. O. Carter, and Professor E. Passarge for their comments; Professor J. H. Peacock and the late Professor A. G. Riddell for their encouragement; and Mrs D. E. B. Roberts and Miss H. M. Hancock for their bibliographical assistance.

T. J. D. is in receipt of a grant from the Medical Research Council.

\section{REPERENCES}

Ahmed, S. (1970). Infantile pyloric stenosis associated with major anomalies of the alimentary tract. Fournal of Pediatric Surgery, 5 , $660-666$.

Blank, R. H., Prillaman, P. E., and Minor, G. R. (1967). Congenital esophageal atresia with tracheoesophageal fistula occurring in identical twins. Fournal of Thoracic and Cardiovascular Surgery, 53, $192-196$.

Bolam, D., Severn, C. B., Ferlic, R., and Van Leeuwen, G. (1973). Esophageal atresia with tracheoesophageal fistula in twins. Nebraska Medical fournal, 58, 329-331.

Butler, N. R. and Alberman, E. D. (Eds.) (1969). Perinatal Problems. The Second Report of the 1958 British Perinatal Mortality Survey, p. 293. Churchill Livingstone, Edinburgh.
Cohen, A. M. and Schenker, J. G. (1972). The effect of insulin treatment on fetal mortality and congenital malformations in diabetic pregnant women. In Drugs and Fetal Development, ed. by M. A. Klingberg, A. Abramovici, and J. Chemke, pp. 377-381. Plenum Press, London and New York.

Copleman, B., Cannata, B. V., and London, W. (1950). Tracheoesophageal anomaly in siblings. Fournal of the Medical Society of New fersey, 47, 415.

David, T. J. and O'Callaghan, S. E. (1974a). An epidemiological study of oesophageal atresia. British fournal of Preventive and Social Medicine, 28, 172-176.

David, T. J. and O'Callaghan, S. E. (1974b). Cardiovascular malformations and oesophageal atresia. British Heart fournal, 36, 559-565.

David, T. J. and O'Callaghan, S. E. (1974c). Twinning and oesophageal atresia. Archives of Disease in Childhood, 49, 660-662.

Dennis, N. R., Nicholas, J. L., and Kovar, I. (1973). Oesophageal atresia. 3 cases in 2 generations. Archives of Disease in Childhood, 48, 980-982.

Edwards, J. H. (1968). The value of twins in genetic studies. Proceedings of the Royal Society of Medicine, 61, 227-229.

Edwards, J. H., Harnden, D. G., Cameron, A. H., Crosse, V. M., and Wolf, O. H. (1960). A new trisomic syndrome. Lancet, 1, 787-789.

Engel, P. M. A., Vos, L. J. M., De Vries, J. A., and Kuijer, P. J. (1970). Esophageal atresia with tracheoesophageal fistula in mother and child. Fournal of Pediatric Surgery, 5, 564-565.

Farha, S. J., Diener, C. H., and Block, P. R. (1971). Esophageal atresia with tracheo-esophageal fistula occurring in multiple birth. fournal of the Kansas Medical Society, 72, 386-389 and 392.

Födisch, H. J. and Sauer, H. (1972). Totale ösophagolaryngotracheale Längsspalte. Zentralblatt für Allgemeine Pathologie und Pathologische Anatomie, 116, 372-379.

Forrester, R. M. and Cohen, S. J. (1970). Esophageal atresia associated with an anorectal anomaly and probable laryngeal fissure in three siblings. Fournal of Pediatric Surgery, 5, 674-675.

Franken, E. A. and Saldino, R. M. (1969). Hypertrophic pyloric stenosis complicating esophageal atresia with tracheoesophageal fistula. American fournal of Surgery, 117, 647-649.

Freedom, R. M. (1972). The asplenia syndrome: a review of significant extracardiac structural abnormalities in 29 necropsied patients. Fournal of Pediatrics, 81, 1130-1133.

Freedom, R. M., Rosen, F. S., and Nadas, A. S. (1972). Congenital cardiovascular disease and anomalies of the third and fourth pharyngeal pouch. Circulation, 46, 165-172.

Fuijimoto, S. and Manabe, A. (1962). Two cases, sister and brother, with esophageal atresia associated with tracheo-esophageal fistula Advances in Obstetrics and Gynecology (Osaka), 14, 155-158.

Glasson, M. J., Bandrevics, V., and Cohen, D. H. (1973). Hypertrophic pyloric stenosis complicating esophageal atresia. Surgery, 74, 530-535.

Gordon, G., Sutherland, G. R., Bauld, R., and Bain, A. D. (1974) The antenatal diagnosis of trisomy 18. Clinical Genetics, 5, 110112.

Grieve, J. G. and McDermott, J. G. (1939). Congenital atresia of the oesophagus in two brothers. Canadian Medical Association fournal, 41, 185-186.

Grosfeld, J. L., Kontras, S. B., and Sommer, A. (1971). Chromosomal abnormalities of the $E$ group and surgical anomalies in neonates. Surgerv, 69, 451-455.

Haight, C. (1957). Some observations on esophageal atresias and tracheo-esophageal fistulas of congenital origin. Fournal of Thoracic Surgery, 34, 141-172.

Hamilton, J. P. (1969). Atresia of the esophagus: factors affecting survival in 249 cases. Collected Works on Cardio-Pulmonary Diseases, 15, 96-109.

Harris, L. C. and Osborne, W. P. (1966). Congenital absence or hypoplasia of the radius with ventricular septal defect: ventriculoradial dysplasia. Fournal of Pediatrics, 68, 265-272.

Hausmann, P. F., Close, A. S., and Williams, L. P. (1957). Occurrence of tracheoesophageal fistula in three consecutive siblings. Surgery, 41, 542-543.

Holder, T. M., Cloud, D. T., Lewis, J. E., and Pilling, G. P. (1964). Esophageal atresia and tracheoesophageal fistula. A survey of its members by the surgical section of the American Academy of Pediatrics. Pediatrics, 34, 542-549.

Holman, G. H., Erkman, B., Zacharias, D. L., and Koch, H. F. (1963). The 18-trisomy syndrome-two new clinical variants. One with associated tracheoesophageal fistula and the other with 
probable familial occurrence. New England fournal of Medicine, 268, 982-988.

Ingalls, T. H. and Prindle, R. A. (1949). Esophageal atresia with tracheoesophageal fistula. Epidemiologic and teratologic implications. New England fournal of Medicine, 240, 987-995.

Källén, B. and Winberg, J. (1974). Caudal mesoderm pattern of anomalies: from renal agenesis to sirenomelia. Teratology, 9, 99112.

Kalter, H. and Warkany, J. (1957). Congenital malformations in inbred strains of mice induced by riboflavin-deficient, galactoflavincontaining diets. Fournal of Experimental Zoology, 136, 531-553.

Kopec, A. C. (1970). The Distribution of the Blood Groups in the United Kingdom, pp. 62-63. Oxford University Press, London.

Krishinger, G. L. and Woolley, M. M. (1969). Esophageal atresia and tracheo-esophageal fistula. 25 years' experience and current management. California Medicine, 111, 165-168.

Kučera, J. (1971). Rate and type of congenital anomalies among offspring of diabetic women. Fournal of Reproductive Medicine, 7, 73-82.

Kučera, J. and Lenz, W. (1967). Caudale Regression mit Oesophagusatresie und Nierenagenesie-ein Syndrom. Zeitschrift für Kinderheilkunde, 98, 326-329.

Lanman, T. H. (1940). Congenital atresia of the esophagus. A study of thirty-two cases. Archives of Surgery, 41, 1060-1083.

Lazjuk, G. I., Lurie, I. W., Kravtzova, G. I., and Usoev, S. S. (1973) New cytogenetic variant of Orbeli's syndrome $(46, \mathrm{XY} / 45, \mathrm{XY}$, $-\mathrm{D} / 46, \mathrm{XY}, \mathrm{Dq}+)$. Humangenetik, 20, 219-221.

Lewis, E. (1972). Late presentation of stricture of the aqueduct of Sylvius. Australian Paediatric fournal, 8, 287-292.

Mackenzie, M. (1884). A Manual of Diseases of the Throat and Nose, Including the Pharynx, Larynx, Trachea, Oesophagus, Nose and Naso-Pharynx, vol. 2, p. 219. Churchill, London.

Madsen, C. M. (1964). Hirschprung's Disease. Congenital Intestinal Aganglionosis, p. 47. Munksgaard, Copenhagen.

Martin, L. W. (1965). Management of esophageal anomalies. Pediatrics, 36, 342-350.

Myers, N. A. (1973). Oesophageal Atresia-the Epitome of Modern Surgery. Hunterian Lecture 24 July 1973. Royal College of Surgeons of England. (Unpublished.)

Owings, R. S. (1973). Nonoperative Aspects of Pediatric Surgery with Special Emphasis on Surgical Neonatology, p. 94. Warren H. Green, St Louis.
Panse, F. and Gierlich, J. (1949). Zur Pathogenese der Anencephalie (auf Grund der Untersuchung eines Akardius und seines Paarlings). Virchows Archiv, 316, 135-148.

Parkkulainen, K. V., Hjelt, L., and Sulamaa, M. (1959/1960). Anal atresia combined with aganglionic megacolon. Acta Chirurgica Scandinavica, 118, 252-256.

Passarge, E. (1972). Genetic heterogeneity and recurrence risk of congenital intestinal aganglionosis. Birth Defects: Original Article Series, 8, pt. 13, pp. 63-67. National FoundationMarch of Dimes, New York.

Potts, W. J. and Idriss, F. (1960). Review of our experience with atresia of the esophagus with and without complicating fistulae. Maryland State Medical fournal, 9, 528-537.

Rabinowitz, J. G., Moseley, J. E., Mitty, H. A., and Hirschhorn, K. (1967). Trisomy 18, esophageal atresia, anomalies of the radius, and congenital hypoplastic thrombocytopenia. Radiology, 89, 488-491.

Rutten, A. P. M. (1962). Oesophageal Atresia. A Critical Study of the Literature and Report on Sixteen Cases, pp. 40-41. Koersen, Amsterdam.

Schimke, R. N., Leape, L. L., and Holder, T. M. (1972). Familial occurrence of esophageal atresia: a preliminary report. Birth Defects: Original Article Series, 8, pt. 13, pp. 22-23. National Foundation-March of Dimes, New York.

Sloan, H. and Haight, C. (1956). Congenital atresia of the esophagus in brothers. Fournal of Thoracic Surgery, 32, 209-215.

Thomson, A. M., Billewicz, W. Z., and Hytten, F. E. (1968). The assessment of fetal growth. fournal of Obstetrics and Gynecology of the British Commonwealth, 75, 903-916.

Warkany, J. (1971). Congenital Malformations. Notes and Comments, p. 679. Year Book Medical Publishers, Chicago.

Warkany, J., Passarge, E., and Smith, L. B. (1966). Congenital malformations in autosomal trisomy syndromes. American fournal of Diseases of Children, 112, 502-517.

Wayson, E. E., Garnjobst, W., Chandler, J. J., and Peterson, C. G. (1965). Esophageal atresia with tracheoesophageal fistula. Lessons of a quarter century's experience. American fournal of Surgery, 110, 162-167.

Woolley, M. M., Chinnock, R. F., and Paul, R. H. (1961). Premature twins with esophageal atresia and tracheoesophageal fistula. Acta Paediatrica, 50, 423-430. 